\title{
Implementation Location-Based Service (LBS) on Mobile Application for Searching Dormitory
}

\author{
Moh Hasan Basri ${ }^{1}$ \\ Information System \\ Faculty of Engineering And Computer Science \\ University Buana Perjuangan \\ Karawang \\ si17.mohbasri@mhs.ubpkarawang.ac.id
}

\author{
Aprilia Hananto ${ }^{2}$ \\ Information System \\ Faculty of Engineering And Computer Science \\ University Buana Perjuangan \\ Karawang \\ aprilia.hananto@ubpkarawang.ac.id
}

\author{
Siti Masruroh ${ }^{3}$ \\ Information System \\ Faculty of Engineering And Computer Science \\ University Buana Perjuangan \\ Karawang \\ siti.masruroh@ubpkarawang.ac.id
}

$\longrightarrow\langle\boldsymbol{\beta}\rangle$

Abstract-The growth of mobile features, especially Smartphones at this time can be said to be very developed. Judging from the increasing number of mobile users, the availability of various mobile features is also growing very rapidly. In line with these facts, the author aims to create a mobile Dormitory application using Location-Based Service (LBS) technology with the application of the Haversine method, making it easier for users to find the closest Dormitoryto their place of work with appropriate facilities. This application is not only to search for Dormitorys, it can also place orders online, this is also an opportunity for the manager or owner of the Dormitoryto promote their Dormitory. Methods of data collection are done by observation, interviews, literature studies, and documentation. The development of this application system uses the Waterfall method. The final result of this research will create an android-based Dormitory mobile application that can make it easier for Dormitoryseekers to search and book Dormitorys as well as a means of promotion for Dormitoryowners and managers.

Keywords-Android, Haversine, Location-Based Service, Mobile Dormitory, Waterfall

Abstrak-Pertumbuhan fitur mobile khususnya Smartphone saat ini dapat dikatakan sangat berkembang. Dilihat dari peningkatan jumlah pengguna ponsel, ketersediaan berbagai fitur ponsel juga berkembang sangat pesat. Sejalan dengan fakta tersebut, penulis bertujuan untuk membuat aplikasi mobile kost menggunakan teknologi Location Based Service (LBS) dengan penerapan metode Haversine, sehingga memudahkan pengguna untuk mencari kost terdekat dengan tempat kerjanya dengan tepat. fasilitas. Aplikasi ini tidak hanya untuk mencari tempat kost, juga dapat melakukan pemesanan secara online, hal ini juga menjadi peluang bagi pengelola atau pemilik kost untuk mempromosikan kostnya. Metode pengumpulan data dilakukan dengan observasi, wawancara, studi pustaka, dan dokumentasi. Pembangunan sistem aplikasi ini menggunakan metode Waterfall. Hasil akhir dari penelitian ini akan membuat sebuah aplikasi mobile kost berbasis android yang dapat mempermudah pencari kost untuk mencari dan memesan kost serta sebagai sarana promosi bagi pemilik dan pengelola kost.

Kata Kunci-Android, Haversine, Layanan Berbasis Lokasi, Mobile Dormitory, Waterfall

\section{PRELIMINARY}

Karawang Regency is an area in West Java province which has an area of $1,753.27 \mathrm{Km} 2$ or 3.73 percent of the area of West Java province with a population of 2,336,009 people [1]. Karawang is known as a big industrial city in Indonesia. This can be seen from the number of companies that are established in Karawang. Therefore, many immigrants from various cities come to work for companies in this city. Migrants who mostly don't know the area in Karawang generally have problems finding Dormitorys around the company where they work, especially Dormitorys with the closest distance from the company. On the other hand, Dormitoryowners find it difficult to promote or publicize available rooms or Dormitorys.

The growth of mobile features, especially smartphones at this time, can be said to be very developed. Judging from the increasing number of mobile users, the availability of mobile features is also growing very rapidly and internet technology has progressed very drastically. The Internet has become a very effective means of information and communication. With the internet, various information in the world can be obtained quickly. Currently, android applications are widely used in various fields, one of which is in the field of business which has implemented many android applications and has been proven to provide benefits to the community [2].

Based on this background, the author aims to design an application with the title "Mobile Dormitory Application Karawang Using Location-Based Service (LBS)", which can be used as a means to assist users in finding Dormitorys based on the closest distance and knowing the Dormitory address and information about other Dormitorys., and on the application, you can order Dormitorys online. With the presence of this Dormitory application, users can search for 
the nearest Dormitoryand book a Dormitory. This application is made with the Java programming language based on Android and to determine the closest distance by utilizing Location Based Service (LBS) using the Haversine Formula [3].

\section{RESEARCH METHODS}

The methods used in this study are data collection methods, Waterfall system development methods, Haversine Formula to determine the closest distance in finding a Dormitoryin the application built, and Location-Based Service to connect the user's location by utilizing the Global Positioning System which is already available on mobile devices. 4].

\section{Method of collecting data}

In the data collection method, the researchers used four ways, including:

\section{1)Observation}

Researchers visited and made direct observations to several Dormitorys in Karawang, these observations were like seeing and checking the overall state of the Dormitorysuch as the state of the Dormitory rooms and available facilities. The results of observations are in the form of facts and information about the state of the Dormitory.

\section{2)Interview}

Conduct direct interviews with Dormitoryowners about how to order, pay and market the Dormitoryand ask for information about the Dormitorysuch as the name of the Dormitory, Dormitory address, Dormitory rules, and others. The results of this interview are in the form of Dormitory data that can be used as material for designing applications to be made. Then, interview the Dormitoryseekers about how or the methods used so far to search for Dormitorys and how to order them. The results of interviews with Dormitoryresidents are in the form of information that can later be used as the need for designing applications to be made.

\section{3) Literature Study}

This literature study was conducted to obtain theoretical references related to the research topic raised, this theory can be obtained from several sources such as journals and theses.

4) Documentation

The documentation carried out in this study such as taking pictures of the Dormitorywith a smartphone camera, existing facilities, and other images that support the process of this research.

\section{System Development Method}

The development of this system uses the Waterfall method [5], while the stages in the development of this system are as follows:

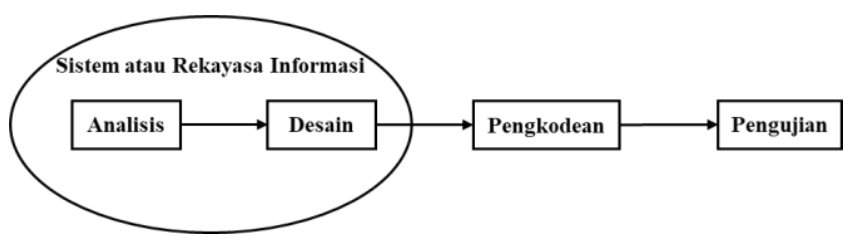

Figure 1 Model Waterfall

\section{1) Needs Analysis (Requirements Analysis)}

At this stage, intensive requirements collection is carried out to determine software requirements so that users can understand the type of software needed [6].

2) Design (Design)

System design is a stage that focuses on the appearance of the system, including data structures, system software architecture, and system interfaces. This stage is designed to meet user needs by using a system in the form of designing a mobile application system display, such as searching for Dormitory rooms based on location or Location-Based Service (LBS) with the Haversine method [3].

3) Implementation (Coding)

This stage is the coding stage of the program which is the implementation process in the form of an order or the realization process of the command form, and the computer can use a programming language to understand the process. The Mobile Application System that will be created uses the Java programming language using Android Studio and the Firebase Database. This implementation phase includes the application of the Haversine Formula to determine the closest Dormitory distance in the application [7].

\section{4) Testing (Testing)}

This testing stage is to ensure that the system that has been completed is by the designer's design, to find out whether the implemented functions can be used in the process of making and designing the Mobile application system.

\section{Haversine Formula}

The Harvesine method is used to calculate the longitude of two points on the earth's surface based on latitude and longitude. Haversine Formula requires inputting the longitude and latitude of the user's location. The following is the formula of Haversine [8].

$$
\begin{aligned}
& \chi=(\text { Long } 1-\text { Long } 2) * \cos \left(\frac{\text { Lat } 1+\text { Lat } 2}{2}\right) \\
& \gamma=(\text { Lat } 1-\text { Lat } 2) \\
& d=\operatorname{sqrt}(x * x+y * y) * R
\end{aligned}
$$

Figure 2 Haversine Formula

Information :

Lat1 = Degree latitude of starting point

Long1 = Degree longitude starting point

Lat2 $=$ Degree latitude of destination point

Long2 $=$ Degree longitude of destination point

$\mathrm{x}=$ Longitude (Longitude)

$\mathrm{y}=$ Latitude (Latitude)

$\mathrm{d}=$ Distance $(\mathrm{Km})$

1 degree $=0.0174532925$ radians

$\mathrm{R}=6371 \mathrm{Km}$

From the above formula, the following is a distance calculation using the Haversine Formula and an analysis of 
the Haversine Formula calculation. This calculation is to measure the distance by using a sample of two locations, namely from the starting point of Karawang International Industrial City to the destination point of Griya Kost.

Location 1 Karawang International Industrial City

Is known :

$$
\begin{aligned}
& \text { Latitude }=-6.359197486564478 \\
& \text { Longitude }=107.2742426711646 \\
& \text { Location } 2 \text { Griya Kost }
\end{aligned}
$$

Is known :

Latitude $=-6.352268604491233$

Longitude $=107.309655751302$

Difference in Longitude Locations 1 and 2

Difference $=$ Longitude Location 1 - Longitude Location 2

Difference $=107.2742426711646-107.3096557511302$

Difference $=-0.03541307997$

Convert Latitude Location 1,Location 2,Longitude Difference to $\mathrm{Rad}$

Conversion result Latitude Location $1=-0.110988933924$ $\mathrm{rad}$

Latitude Location $2=-0.110868002119 \mathrm{rad}$. conversion result

Longitude Difference conversion result $=-0.000618074843$ $\mathrm{rad}$

Calculates SIN from latitude of Locations 1 and 2 which has been converted to Rad

SIN calculation results Location $1=-0.1107612039$

SIN calculation results Location $2=-0.1106410154$

Calculates COS from latitude of Location 1, Location 2 and Longitude Difference converted to Rad

COS calculation results Location $1=0.9938470484$

COS calculation results Location $2=0.9938604357$

COS calculation result Longitude Difference $=0.999999809$

Calculates the distance between Location 1 to Location 2

Distance $=($ SIN Location $1 *$ SIN Location 2$)+($ COS Location $1 *$ COS Location $2 *$ COS Longitude Difference)

Distance $=(-0.1107612039 *-0.1106410154) \quad+$ $(0.9938470484 * 0.9938604357 * 0.999999809)$

Distance $=0.9999998039$

Calculating distance result to ACOS

Distance $=\operatorname{ACOS}(0.9999998039)$

Distance $=0.00062618$

Convert ACOS distance results to Degrees

Distance $=0.03587747121559$

Converting distance results from Degrees to Kilometers (KM)
Distance $=0.03587747121559 * 60 * 1.1515$

Distance $=2,478774486$

Determine the final result

Distance $=2.478774486 * 1.609344$

Distance $=3.989200846$ KM 4 KM

The result of the above calculation is $3.989200846 \mathrm{~km}$ which is calculated from the starting point of Karawang International Industrial City and the destination point of Griya Kost.

\section{RESULTS AND DISCUSSION}

\section{Running System Analysis}

The current system analysis aims to see the process of finding a Dormitoryin Karawang City which is still being carried out by visiting from one Dormitoryto another to see the state of the Dormitorydirectly. The following is a flowmap on a system that is ongoing or currently running [9].

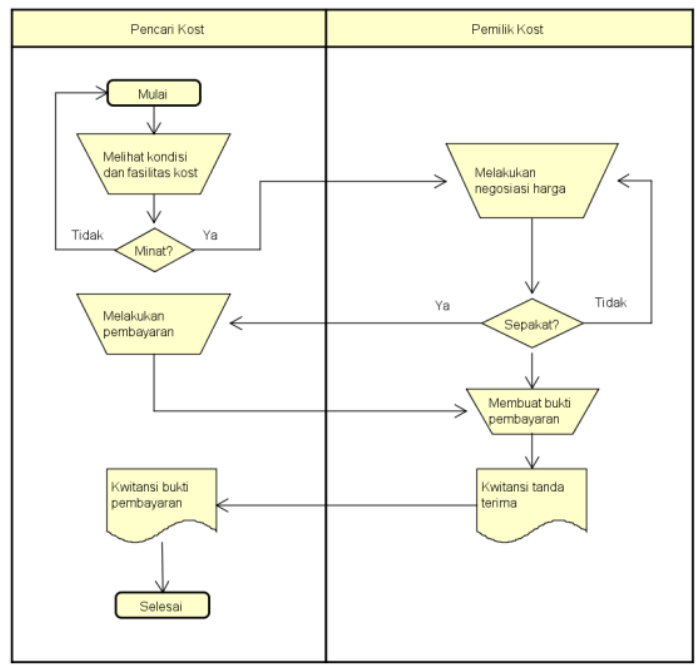

Figure 3 Flowmap of the Running System

\section{Proposal System}

This design aims to meet all the needs of the users of the system to provide a clear and understandable picture. The proposed system describes the system to be built. The system design is made in the form of a Flowmap, starting from the user opening the application, until the user manages to get a Dormitory. The system design to be built is described in the form of a Flowmap as shown in the following figure: 


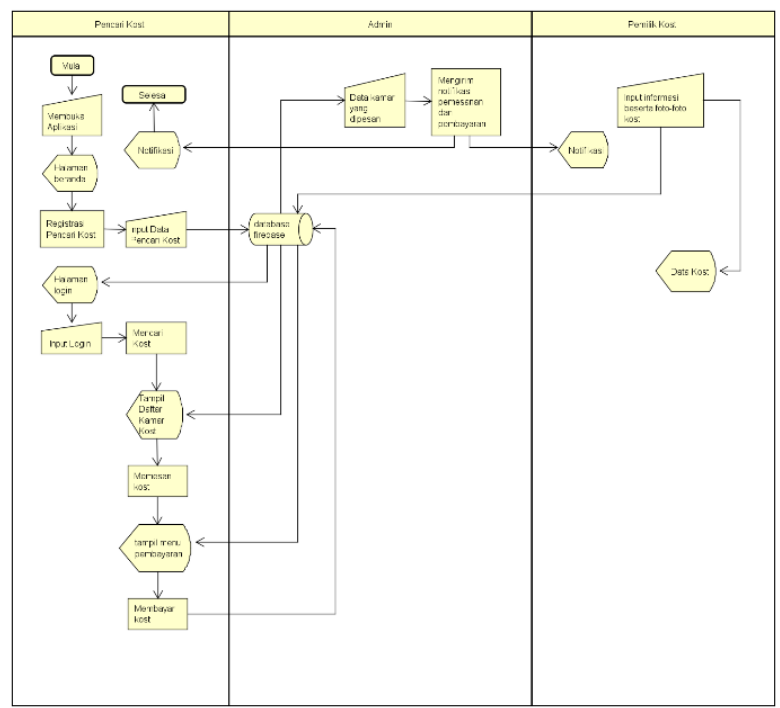

Figure 4 Flowmap of the Proposed System

\section{Usecase Diagram}

Usecase Diagram is a description of the actors and the needs of the usecase functions needed in the system [10]. The following is an image of the proposed use case diagram:

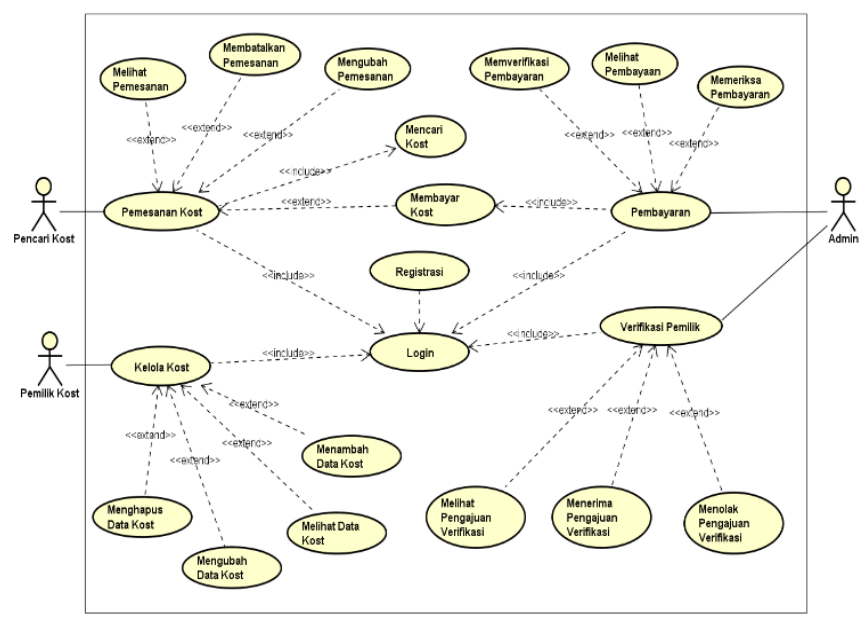

Figure 5 Usecase Diagram of the Proposed System

The proposed system uses a use case diagram explaining the system to be built with actors such as Dormitoryseekers, Dormitoryowners, and admins with their respective access.

\section{Sequence Diagram}

The sequence is generally used to describe a scene or a series of steps taken in response to an event to produce a certain output, as well as what has changed internally and what kind of output has been produced. The following is a modeling of the Mobile Kost Karawang application using a Sequence Diagram. Below is an image of the Sequence Diagram of the proposed search:

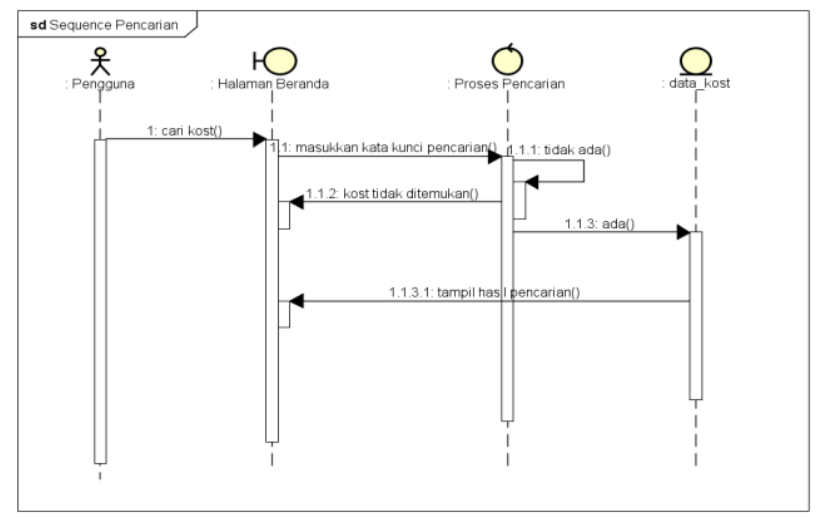

Figure 6 Kost Search Sequence Diagram

The picture above is a sequence diagram for the Dormitorysearch, in which the user enters the search keyword on the home page, then the system processes the search and the system results will display the search Dormitory results taken from the Dormitory data.

\section{Class Diagram}

Class diagrams or class diagrams describe the structure of the system in terms of defining the classes that will be created to build the system. With class diagrams, you can make detailed diagrams by paying attention to the specific codes needed by the program and this can be applied to the structure described. The following is a class diagram on a Dormitory mobile application.

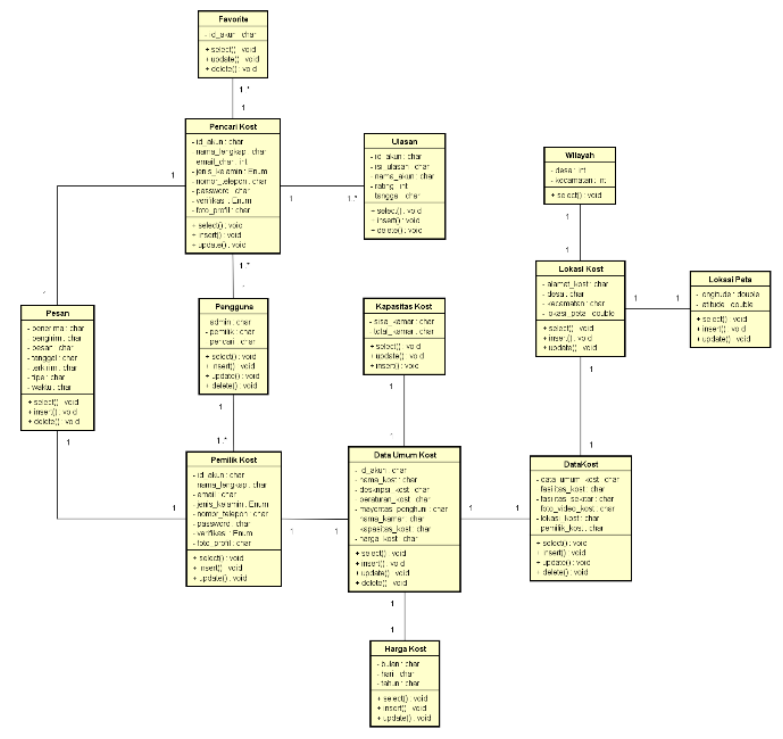

Figure 7 Class Diagram of the Mobile Dormitory Application

\section{Implementasi Location-Based Service (LBS)}

Location-Based Service (LBS) is used in the system, especially in conducting searches that can be connected to google maps. The result of Location-Based Service (LBS) is the point from the place or location of the Dormitorythat will be stored in the system [11]. 
LBS implementation begins by finding the last location with latitude and longitude points from the Global Positioning Service (GPS) connected to the user's mobile device. This LBS is connected to google maps so that when it is determined the google maps display will match the user's location.

\section{Implementasi Haversine}

The distance determination is generated from calculations using the Haversine Formula, the values used are the longitude and latitude points from the starting point to the destination point.

The Haversine Formula begins by calculating the difference between the initial longitude point and the destination longitude point. Then the value of the latitude of the starting point and the latitude of the destination and the difference between the longitudes are converted into radians. Then calculate sin and cos from the results that have been converted from the value of the starting point and the destination point, but to calculate cos including the results of calculating the difference in longitude of each point [8].

\begin{tabular}{|c|c|c|c|c|c|c|}
\hline \multirow{2}{*}{ No } & \multicolumn{2}{|c|}{ Titik Mulai } & \multicolumn{2}{c|}{ Titik Tujuan } & \multirow{2}{*}{ Haversine } & $\begin{array}{l}\text { Google } \\
\text { Maps }\end{array}$ \\
\cline { 2 - 6 } & Latitude 1 & Longitude 1 & Latitude 2 & Longitude 2 & & \\
\hline 1. & $-6,359197487$ & 107,2742427 & $-6,352268604$ & 107,3096558 & $3.98 \mathrm{~km}$ & $3.99 \mathrm{~km}$ \\
\hline 2. & $-6,327623336$ & 107,2877780 & $-6,323338243$ & 107,3012788 & $1.56 \mathrm{~km}$ & $1.57 \mathrm{~km}$ \\
\hline 3. & $-6,301365223$ & 107,2780176 & $-6,304240781$ & 107,2978055 & $2,19 \mathrm{~km}$ & $2,20 \mathrm{~km}$ \\
\hline
\end{tabular}

The distance generated from the product of the starting point $\sin$ and the destination point $\sin$ is added up by the product of the starting point cos and destination point cos and the longitude difference cos. The result is converted to kilometers after finding across and multiplied by $60 * 1.1515$ and multiplied by 1.609344 to produce the distance in kilometers [12].

\section{Haversine Formula Calculation Analysis}

The analysis of the Haversine Formula calculation uses three sample data. The results of calculations with the Haversine Formula can be seen in the following table:

Table 1 Calculation Results of Haversine

\begin{tabular}{|c|c|c|c|c|c|}
\hline \multirow{2}{*}{ No } & \multicolumn{2}{|c|}{ Titik Mulai } & \multicolumn{2}{c|}{ Titik Tujuan } & \multirow{2}{*}{ Haversine } \\
\cline { 2 - 5 } & Latitude 1 & Longitude 1 & Latitude 2 & Longitude 2 & \\
\hline 1. & $-6,359197487$ & 107,2742427 & $-6,352268604$ & 107,3096558 & $3.98 \mathrm{~km}$ \\
\hline 2. & $-6,327623336$ & 107,2877780 & $-6,323338243$ & 107,3012788 & $1.56 \mathrm{~km}$ \\
\hline 3. & $-6,301365223$ & 107,2780176 & $-6,304240781$ & 107,2978055 & $2,19 \mathrm{~km}$ \\
\hline
\end{tabular}

After calculating with the Haversine Formula, the researcher made an experiment using Google Measurement to measure the distance. This experiment was made by entering the coordinates of the start point and endpoint in Google Maps to measure, then using the distance measurement function by drawing a straight line from the starting point to the endpoint that was already available on Google Maps. This distance calculation experiment can be seen in the following figure:

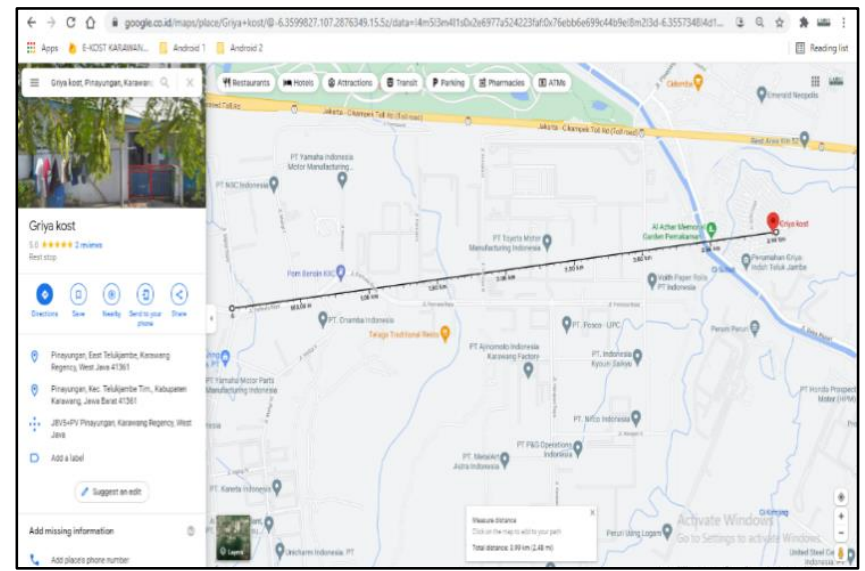

Figure 8 Google Measurement

Based on the comparison of distance measurements using Haversine Formula and Google Maps, there are differences in distance measurement results of 0-10 meters. comparison of distance measurement results as in the following table:

Table 2 Comparison of Distance Measurement

\section{Interface Design}

The design of the interface or the interface on the software is used to connect the interaction between the user and the software to be made [13]. Interface design or system display is made using pencil software. The interface design of the system building can be seen as shown below [14].

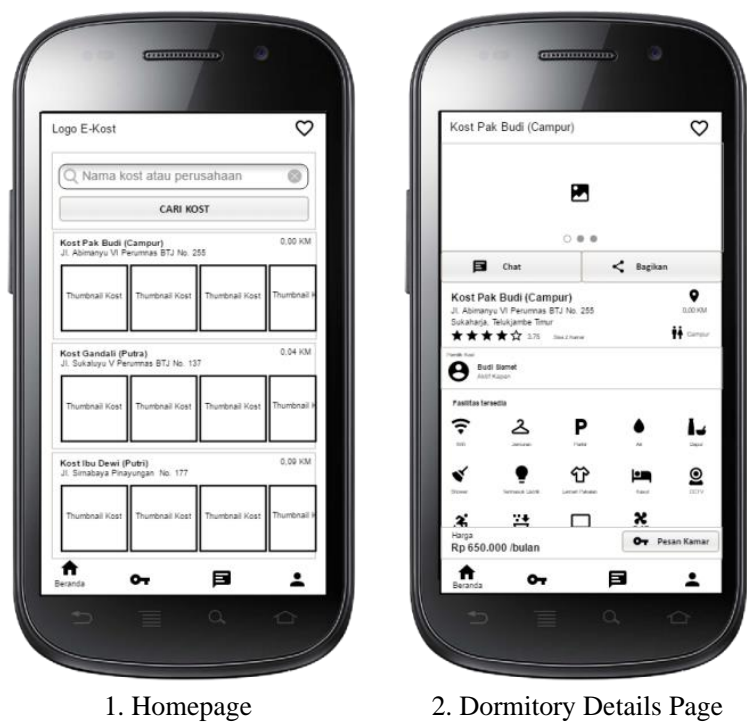




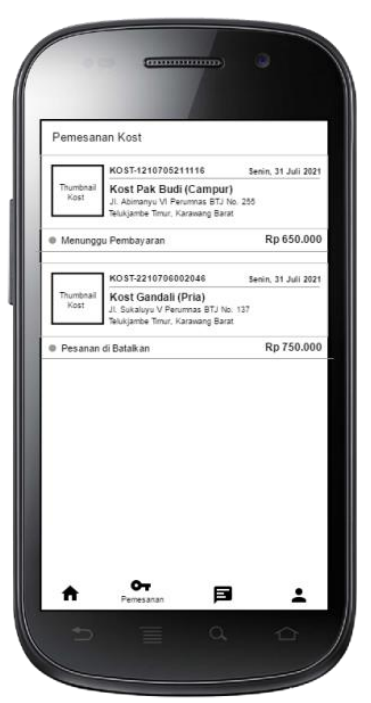

3. Order Page

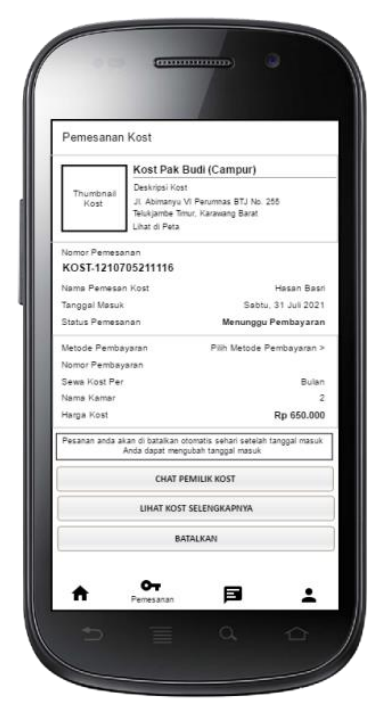

4. Order Details Page

\section{System View Implementation}

After performing the previous stage of analyzing the current system and designing the proposed system, then the process of implementing the system display Here is the display of the Dormitory mobile application:

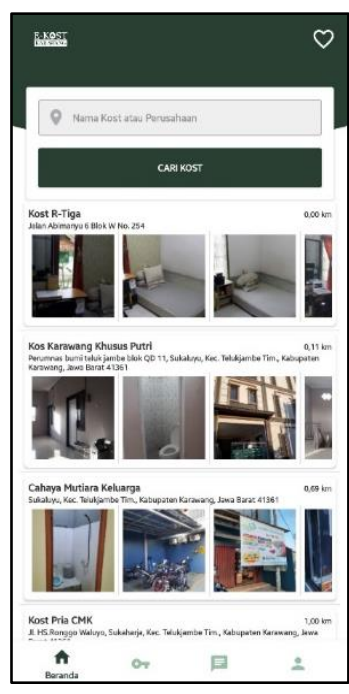

1. Homepage

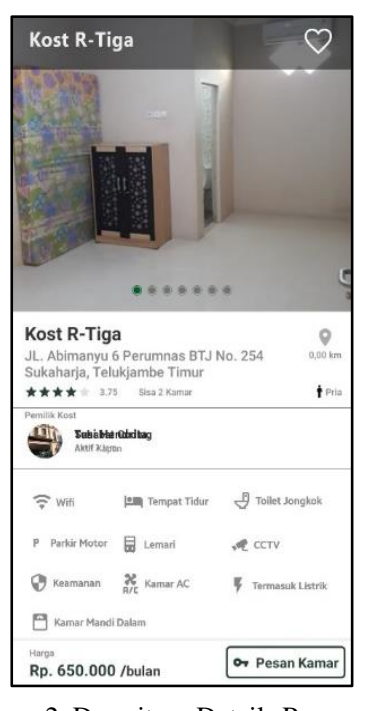

2. Dormitory Details Page

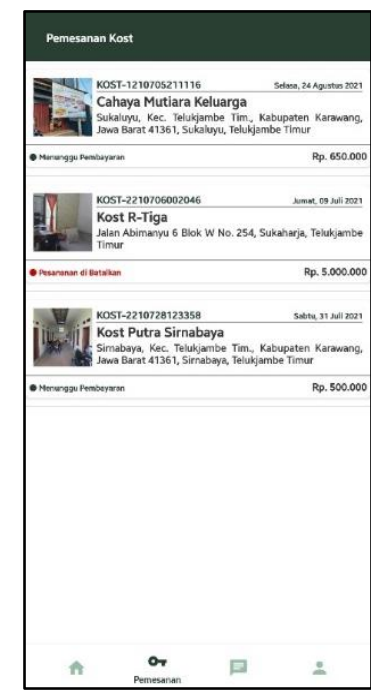

3. Order Page

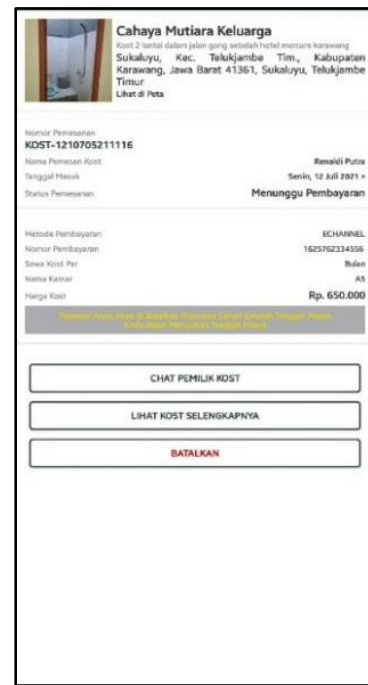

4. Order Details Page
Figure 1 is the home page, on this page, there is a Dormitory search column to find a Dormitoryby inputting the company name or Dormitoryname, then when pressing the search button a list of Dormitorys will appear based on the closest distance from the destination company. Figure 2 is a page for displaying Dormitory in detail such as addresses, categories, ratings or ratings, as well as available Dormitory facilities

Figure 3 is a Dormitory booking page, this page displays Dormitory orders and can be seen in detail by selecting an order, a page like a Figure 4 will appear which contains ordering data and can be inputted by the customer as needed.

\section{Black Box Test}

Black Box testing is centered on the functional requirements of the software. Black box testing makes it possible in software engineering to obtain a set of input, process, and output conditions that are completely in sync with the functionality of a program.

The system testing phase is carried out after the system implementation phase is complete. The execution of the test phase is to re-examine all the phases that have been run to find or find errors. The purpose of system testing is to ensure that the system that has been built will function as expected. The following is a table of the results of testing the system interface function using Black Box testing [15].

Table 3 System Interface Testing

\begin{tabular}{|l|l|c|c|c|c|}
\hline No. & $\begin{array}{l}\text { Test } \\
\text { Name }\end{array}$ & User & \multicolumn{1}{|c|}{ Expected results } & \multicolumn{1}{c|}{$\begin{array}{c}\text { Test } \\
\text { result }\end{array}$} & $\begin{array}{c}\text { Status } \\
\text { Uji }\end{array}$ \\
\hline 1. & $\begin{array}{l}\text { Login } \\
\text { Page }\end{array}$ & $\begin{array}{l}\text { Dormits } \\
\text { y Finde } \\
\text { Dormit } \\
\text { y Owne } \\
\text { Admin }\end{array}$ & $\begin{array}{l}\text { The system can display the login } \\
\text { page interface when opening the } \\
\text { Mobile system. The login process } \\
\text { can be done by inputting text or } \\
\text { logging in via a Google account } \\
\text { automatically }\end{array}$ & $\begin{array}{l}\text { login } \\
\text { page can } \\
\text { displayed. }\end{array}$ & $\sqrt{ }$ \\
\hline 2. & $\begin{array}{l}\text { Homep } \\
\text { age }\end{array}$ & $\begin{array}{l}\text { Cost } \\
\text { Finder }\end{array}$ & $\begin{array}{l}\text { The system can display the home } \\
\text { page interface after successful } \\
\text { login. }\end{array}$ & $\begin{array}{l}\text { the home } \\
\text { page can } \\
\text { be } \\
\text { displayed. }\end{array}$ & $\sqrt{ }$ \\
\hline 3. & $\begin{array}{l}\text { Dormit } \\
\text { ory } \\
\text { Details } \\
\text { Page }\end{array}$ & $\begin{array}{l}\text { Cost } \\
\text { Finder }\end{array}$ & $\begin{array}{l}\text { The system can display the } \\
\text { Dormitory detail page }\end{array}$ & $\begin{array}{l}\text { Dormitory } \\
\text { detail page } \\
\text { can be } \\
\text { displayed }\end{array}$ & $\sqrt{ }$ \\
\hline
\end{tabular}




\begin{tabular}{|l|l|l|l|l|l|}
\hline 4. & $\begin{array}{l}\text { Search } \\
\text { Page }\end{array}$ & $\begin{array}{l}\text { Cost } \\
\text { Finder }\end{array}$ & $\begin{array}{l}\text { The system can display a list of } \\
\text { Dormitorys that are sought in order } \\
\text { based on the closest to the furthest } \\
\text { distance }\end{array}$ & $\begin{array}{l}\text { the search } \\
\text { page can } \\
\text { be } \\
\text { displayed }\end{array}$ & $\sqrt{ }$ \\
\hline 5. & $\begin{array}{l}\text { Order } \\
\text { Page }\end{array}$ & $\begin{array}{l}\text { Cost } \\
\text { Finder }\end{array}$ & $\begin{array}{l}\text { The system can display the order } \\
\text { page }\end{array}$ & $\begin{array}{l}\text { order page } \\
\text { can be } \\
\text { displayed }\end{array}$ & $\sqrt{ }$ \\
\hline 6. & $\begin{array}{l}\text { Dormit } \\
\text { ory } \\
\text { Manage } \\
\text { ment } \\
\text { Page }\end{array}$ & $\begin{array}{l}\text { Dormits } \\
\text { Admin }\end{array}$ & $\begin{array}{l}\text { The system can display a an } \\
\text { Dormitory management page, on } \\
\text { this page the Dormitoryowner can } \\
\text { add, view, change and delete } \\
\text { Dormitorys. Admin can view and } \\
\text { disable Dormitory }\end{array}$ & $\begin{array}{l}\text { Dormitory } \\
\text { manageme } \\
\text { nt page can } \\
\text { be } \\
\text { displayed }\end{array}$ & $\sqrt{ }$ \\
\hline
\end{tabular}

\section{CONCLUSIONS AND SUGGESTIONS}

Based on the research that has been done and the test results of the mobile Dormitory application using LocationBased Service (LBS) with the Haversine Formula, it can be concluded that:

1. A Dormitory mobile application has been built that can display the location of the closest Dormitoryfrom a company in Karawang, this method uses the Haversine Formula to determine the closest distance where Haversine is a formula that measures the distance between two points by drawing a straight line between the two points. This formula ignores terrain or obstacles when measuring these two points.

2. The application can provide detailed Dormitory information needed by Dormitoryseekers such as Dormitory addresses, Dormitory pictures, available facilities, prices, and other information.

\section{REFERENCE}

[1] "Karawang Kabupaten." [Online]. Available: sumber:https://karawangkab.bps.go.id.

[2] Bayu Priyatna and Fitria Nurapriani, "Implementasi Koordinat Google dan Citra Kamera Pada Aplikasi Monitoring Petugas Berbasis Android," Buana Ilmu, vol. 5, no. 1, pp. 106-121, 2020.

[3] G. F. Laxmi, F. Satrya, and F. Kusumah, "Perancangan Location Based Service ( Lbs ) Pada Pencarian Event Aplikasi Sahabat Jasa Berbasis Android," pp. 297-306, 2018.

[4] I. A. Murdiono, "Naskah publikasi perancangan aplikasi mobile location based service (lbs) untuk pencarian lokasi rumah kos di kota sleman berbasis android," 2020.

[5] D. Rancadaka, "Aplikasi Penjualan Padi Berbasis Web Dengan Menggunakan Metode," vol. 1, no. 1, pp. 29-33, 2020.

[6] B. Priyatna, S. Shofia Hilabi, N. Heryana, and A. Solehudin, "Aplikasi Pengenalan Tarian Dan Lagu Tradisional Indonesia Berbasis Multimedia," Systematics, vol. 1, no. 2, p. 89, 2019.

[7] B. Huda and B. Priyatna, "Penggunaan Aplikasi Content Management System (CMS) Untuk Pengembangan Bisnis Berbasis E-commerce," Systematics, vol. 1, no. 2, p. 81, 2019.

[8] H. Kusniyati and H. Fadhillah, "Aplikasi Pencarian Ustadz Untuk Wilayah Dki Jakarta Menggunakan Algoritma Haversine Formula Berbasis Android," Petir, vol. 9, no. 2, pp. 102-111, 2019.

[9] H. Gunawan and A. K. H. Saputro, "Pemanfataan Aplikasi Mobile Untuk Mempercepat Pencarian Tempat Indekos Berbasis Android," J. Muara Sains, Teknol. Kedokt. dan Ilmu Kesehat., vol. 1, no. 2, pp. 85-96, 2018.

[10]S. Anton, I. C. Alex, and N. Kristiawan, "Sistem Penilaian Kinerja Pegawai dalam Pelayanan Nasabah pada ... (Sujarwo dkk.)," Penilaian, Sist. Pegawai, Kinerja Nasabah, Pelayanan Kinerja, Abstr. Lang. Unified Model., pp. 270-275, 2019.

[11]M. Ahmad, S. Al-Ikhsan, and F. Satri, "Pengembangan Aplikasi Pencarian Wisata Kuliner Kota Bogor Berbasis Range Harga Dan Metode LBS (Location Base Servise) Pada Android," Inovatif, vol. 1, no. 2, pp. 1-5, 2018.

[12]A. M. Abdillah, R. Rianto, and N. I. Kurniati, "Penerapan Metode Haversine Pada Aplikasi Layanan Perbaikan Kendaraan Berbasis Location Based Service," JUITA J. Inform., vol. 7, no. 2, p. 81, 2019.

[13]B. Priyatna and A. Hananto, "Implementation of Application Programming Interface (API) in Indonesian Dance and Song Applications," Systematics, vol. 2, no. 2, pp. $47-57,2020$.

[14]Gelinas, Ulric, Oram, Alan, Wiggins, and William, "Accounting Information System," pp. 17-30, 1990.

[15]A. Ukur, "Sistem Informasi Monitoring Kualitas Alat Ukur," no. Ciastech, pp. 419-428, 2020. 